\title{
Metodologías participativas con un enfoque intercultural e intergeneracional. Una experiencia educativa en la ciudad
}

\section{Participatory Methodology with an Intercultural and Intergenerational Approach: An Educational Experience in the City}

\author{
José Alberto Gallardo-López. \\ Universidad Internacional Isabel I. \\ josealberto.gallardo@ui1.es
}

David Muñoz Villaraviz. Colegio de Educación Infantil y Primaria San José Obrero. davidvillaraviz@gmail.com

\section{RESUMEN.}

Esta investigación recoge una experiencia docente en el marco de un proyecto de innovación educativa de la Junta de Andalucía, cuyo eje vertebrador es una Muestra Anual de Comunicación (MuAC) que, tras tres ediciones, se ha consolidado como un espacio de encuentro entre educadores y alumnado de todas las edades, diferentes culturas y realidades socioeducativas. El objetivo principal es convertir al estudiante en el protagonista de su aprendizaje, en contextos intergeneracionales e interculturales, además de mostrar y compartir buenas prácticas educativas en espacios emblemáticos de la ciudad. De esta forma, las personas implicadas intercambian experiencias docentes a través de metodologías participativas que garantizan un aprendizaje significativo y permiten visibilizar las múltiples tareas educativas innovadoras que se llevan a cabo en los centros educativos. El estudio realizado analiza, desde una metodología cuantitativa, la información recogida en las tres ediciones de la MuAC y establece una comparación, en la que se refleja el número de participantes por año de edición, niveles educativos, centros docentes participantes, el conjunto de talleres y actividades socioeducativas realizadas y el grado de satisfacción de la experiencia. Tras el análisis, deducimos que la experiencia fue altamente satisfactoria, llegando a participar en la edición de 2018 más de 1000 estudiantes y 87 docentes, pertenecientes a 12 colegios, 9 institutos de educación secundaria, 1 universidad y 12 organizaciones socioeducativas. Este tipo de actividades mejoran las relaciones sociales, promueven los procesos de enseñanza-aprendizaje desde un enfoque intercultural e intergeneracional y amplían el concepto de vecindad entre la ciudadanía que participa.

\section{PALABRAS CLAVE.}

Intercultural, Intergeneracional, Innovación educativa, Metodología participativa.

\section{ABSTRACT.}

This research includes a teaching experience within the framework of an educational innovation project of the Junta de Andalucía, whose backbone is an Annual Communication Sample (MuAC) that, after three editions, has consolidated as a meeting place for educators and students of all ages, different cultures, and socio-educational realities. The main objective

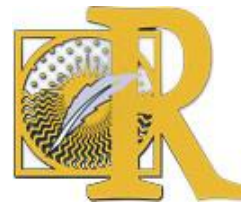

Fecha de recepción: 25-02-2019 Fecha de aceptación: 09-07-2020 
is to turn students into the protagonist of their learning, in inter- regional and intercultural contexts, besides showing and sharing sound educational practices in emblematic areas of the city. This way, people involved exchange their experiences with teachers through participatory methodologies that favor meaningful learning. They also make visible the multiple innovative educational tasks that are carried out in their educational centre. The study basically analyzes from a quantitative methodology, information collected in the three editions of the MuAC and establishes a comparison, in which the number of participants for year of publication are reflected, educational levels, educational institutions participating, the whole workshops and socio-educational activities carried out, and the degree of satisfaction with the experience. After analysis, we conclude that It was a highly satisfactory experience, we involved in the edition of 2018 more than 1000 students, and 87 teachers from 12 different schools, 9 secondary schools, 1 University, and 12 socio - educational organizations. This type of activity improves social relationships, helps to promote teaching and learning from an intercultural and intergenerational approach, and expands the concept of the neighborhood among the citizenship that has been participating in this experience.

\section{KEY WORDS.}

Intercultural, Intergenerational, Educational Innovation, Participatory Methodology.

\section{Introduction.}

We live in a society in constant change and development, with continuous educational challenges, where common values acquire a fundamental importance. In this sense, "intergenerational programs represent a strategy to act from the school context in favor of a society for all ages, since the school must be a space open to the community" (Abarrategui, 2018, p. 213).

As teachers, we must be aware that society has a shared responsibility when it comes to educating the citizenship that makes it. Thus involving different educational agents in these functions is a very interesting way to develop a common learning.If we propose socioeducational interventions from an intergenerational methodology, involving students of different ages, families, teachers, and different organizations and institutions in the activities proposed to. We are already forming the basis of a very powerful starting point for community education.

Communication is paramount in this teaching-learning environment, "providing diverse possibilities of exchange of experiences through multiple forms of interaction ... it facilitates a sense of belonging, the adoption of different positions, the ability to see their own experiences in the light of others, debate and defend their own choices, address new situations, regulate their own action" (Montero, and Baena, 2013 , p.96).

In addition, the use of new learning techniques and methods to promote inter-culturality, such as cooperative work, is very positive since, by structuring learning from heterogeneous groups working towards a common goal, it improves cognitive development and affective, processes of socialization, critical thinking and academic achievement (Gallardo Vázquez and GallardoLópez, 2011a; Johnson and Johnson, 2009; Santos, 2017; Gallardo-López and Gallardo Vázquez, 2018; Cotán, García-Lázaro and Gallardo-López, 2021). It is important to point out

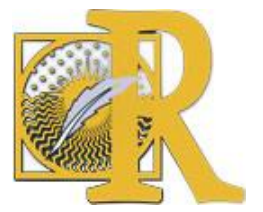

Fecha de recepción: 25-02-2019 Fecha de aceptación: 09-07-2020 
that, in this type of cooperative methodologies, the members of the working group are required to assume an active role, and there is an adequate distribution of the tasks to be carried out. Currently, the increase in multicultural diversity that our society is experiencing is evident. This fact directly affects the situation of the realities in educational centers, where it is clearly recognizable in their classrooms. According to data from the Ministry of Education, Culture and Sports (MECD, 2017), in the Teachings of General Regime in Spain, in the academic year 2006/2007 there were a total of 594,077 foreign students in our educational centers, and this figure increases progressively reaching 687,899 in the academic year $2016 / 2017$. The Autonomous Communities with a higher percentage of foreign students than the total number of students, in the General System Teachings for the 2016/2017 academic year, are the Balearic Islands (13.6\%), La Rioja (12.9\%) and Catalonia (12.4\%). In addition, the percentage origin of these students is: Africa (30.5\%), European Union (29.4\%), America (25.2\%), Asia and Oceania (10.2\%) and the rest of Europe (4.7\%).

These figures invite us to reflect critically on the role that educational centers must fulfill as agents of socialization and construction of multicultural and diverse identities. From a perspective of intercultural pedagogy for diversity, it is essential to create spaces that generate learning that facilitate "a greater understanding, openness and mutual enrichment of students from different cultures" (Chamseddine, 2018, p.197) and to increase empathy and sensitivity towards the knowledge of other forms of behavior and interpretations of social reality (Gallardo Vázquez and Gallardo-López (2011b). According to UNESCO (2006), the cultural diversity coexisting in our societies is a manifestation of the complexity and heterogeneity of life on earth.

On the other hand, the occupation of community territorial spaces turns the school into an institution that acts as a critical actor of social change. In this sense, citizen participation in the community extends the scenarios where social teachings and lessons can be produced to face new challenges with a direct link with the environment. Works as those of Ainscow (2001); Traver, Sales and Moliner (2010); García and Villar (2011); García (2012); Echeita, Simón, Sandoval and Monarca (2013); Lozano, Cerezo and Alcaraz (2015); o Quaresma and Zamorano (2016) point out the possibilities and advantages offered by direct cooperation between the school and the environment, experiencing a transformation and reciprocal feedback.

\section{Material and Methods.}

The General Directorate of Educational Innovation and Teacher Training approves the MuAC project (Reference: PIN-039/16) as a research and educational innovation project, within the scope"Proc those teaching-learning".

The Annual Communication Exhibition (MuAC) is an event where students and teachers of all educational levels participate: Infant Education, Primary, Secondary, Baccalaureate, Training, and Higher Education.

MuAC is a communicative experience, it is a space in which the educational community, and any organization linked to education, can express their concerns and share their knowledge. It is also an intergenerational and intercultural meeting point, where students from different educational levels and different teaching centers interact and create synergies, approaching

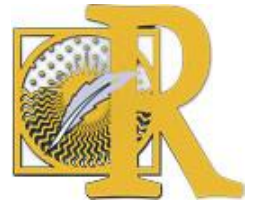

Fecha de recepción: 25-02-2019 Fecha de aceptación: 09-07-2020

Gallardo-López, J. A. \& Muñoz-Villaraviz, D. (2021). Metodologías participativas con un enfoque intercultural e intergeneracional. Una experiencia educativa en la ciudad 
various socio-educational realities. All this takes place in emblematic and neuralgic spaces of the historic center of Seville, where educators and students show and learn from activities that they have previously prepared in their respective educational centers, with an innovative and creative methodological approach.

This educational experience creates a jovial and relaxed atmosphere, conducive to take advantage of the many possibilities that communication has as a fundamental tool to optimize learning, from a formal, non-formal, and informal perspective.

\subsection{Goals.}

The general objectives set to create and consolidate the MuAC are the following:

- Turn students into the protagonist of learning in intergenerational and intercultural contexts.

- Show and share sound educational practices with students, in emblematic locations of the city.

- Expand the possibilities of cooperating, exchanging, and making visible the multiple innovative educational tasks that are carried out in educational centers.

To achieve these general objectives, a series of specific objectives are formulated:

- Create an educational association of teachers to manage the event.

- Consolidate the pedagogical event in the educational agenda of the city of Seville.

- To create an intergenerational and intercultural play space that enriches the autonomy of the students, favoring their teaching- learning process in a cooperative way.

- To optimize the teaching competence in a real framework of exchange of face-to-face experiences.

- Encourage teamwork and collaborative work of all members of the educational community.

\subsection{Evaluation Methodology.}

The valuation methodology carried out in this research is quantitative, and designed and implemented partially through a questionnaire assessment, (Likert), intended to collect information related to various aspects of the experience, such as overall satisfaction after the MuAC event, the educational usefulness of the proposed activities, issues related to educational values, the level of involvement and participation of students, and the benefit obtained in the exchange of experiences of innovative educational practices with other professionals in the sector. The questionnaire was administered and completed online by a sample composed of 34 teachers (MuAC 2016), 49 teachers (MuAC 2017) and 87 teachers (MuAC 2018).

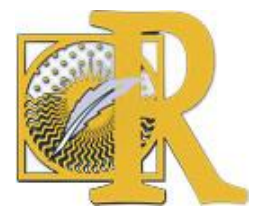

Fecha de recepción: 25-02-2019 Fecha de aceptación: 09-07-2020 
The internal consistency obtained in the questionnaire, as by statistical Cronbach, was 0.771 . In this sense, this value indicates that the internal consistency for the instrument is acceptable ( $\alpha=0.7-0.8$ ) according to the categories proposed by George and Mallery (2003) so that the estimated reliabilitycan be considered as adequate and sufficient.

\section{Results.}

From the constitution of the association to the present day, MuAC has grown in quantity and quality. Proof of this are the results, exposed in this article, of the three editions held: MuAC2016, MuAC 2017 and MuAC 2018.

\subsection{MUAC 2016.}

The first pilot experience took place on March 30 and 31, 2016, at the Palace of the Marquises of Algaba, the House of Sirens, and the Alameda de Hércules in Seville. The first edition featured 16 workshops, where one of the workshops commemorated the thirtieth anniversary of the death of the erudite Argentine writer Jorge Luis Borges.

Table 1. Number of total participants, by courses and educational levels in I MuAC.

\begin{tabular}{|c|c|c|c|c|c|c|c|c|c|c|c|c|}
\hline \multicolumn{13}{|c|}{ MuAC 2016 (278 students per day) } \\
\hline \multicolumn{3}{|c|}{ Childish } & \multicolumn{10}{|c|}{ Primary } \\
\hline 3 years & $\begin{array}{c}4 \text { year } \\
\mathrm{s}\end{array}$ & $\begin{array}{c}5 \text { year } \\
\mathrm{s}\end{array}$ & $1 \mathrm{st}$ & 2nd & 3rd & \multicolumn{2}{|c|}{ 4th } & & & \multicolumn{3}{|c|}{ 6th } \\
\hline 0 & 0 & 2 & 2 & 2 & 2 & \multicolumn{2}{|c|}{27} & & & \multicolumn{3}{|c|}{47} \\
\hline \multirow{2}{*}{\multicolumn{4}{|c|}{ High school }} & \multirow{2}{*}{\multicolumn{2}{|c|}{ High school }} & \multicolumn{4}{|c|}{ Training Cycles } & \multicolumn{2}{|c|}{ Sevilla University } & Other \\
\hline & & & & & & \multicolumn{2}{|c|}{$\begin{array}{c}\text { Grade } \\
\text { Medium }\end{array}$} & \multicolumn{2}{|c|}{$\begin{array}{l}\text { Grade } \\
\text { Higher }\end{array}$} & Grade & Master & \\
\hline $1 \mathrm{st}$ & 2nd & $3 r d$ & 4th & $1 \mathrm{st}$ & 2nd & $1 \mathrm{st}$ & 2nd & $1 \mathrm{st}$ & 2nd & & & \\
\hline 49 & 38 & 30 & 9 & 4 & 0 & 52 & 0 & 10 & 0 & 0 & 0 & 1 \\
\hline
\end{tabular}

The total participation was: 4 schools, 4 institutes, the School of Crafts of Gelves, and the information center Europe Direct Sevilla. Participated, counting both days, more than 30 teachers and more than 400 students. In addition, the experience had a great media impact ${ }^{1}$.

\subsection{MUAC 2017.}

The second experience took place on April 26 and 27, 2017, coinciding with the day that the Universal Exhibition of Seville began in 1992. Of the 31 workshops, 5 commemorated the 25th anniversary of Expo'92. In addition to using the same spaces of celebration as the previous edition of MuAC, a workshop was held in the Casa del Pumarejo, a palace house of the eighteenth century in the historic center of Seville.

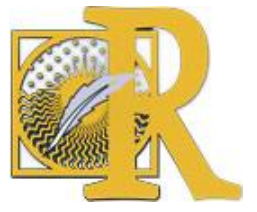

Fecha de recepción: 25-02-2019 Fecha de aceptación: 09-07-2020 
Table 2. Number of total participants, by courses and educational levels in II MuAC.

\begin{tabular}{|c|c|c|c|c|c|c|c|c|c|c|c|c|}
\hline 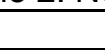 & 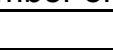 & 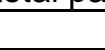 & & $\mathrm{Mul}$ & $17(7$ & stud & nts pe & lay) & & & & \\
\hline & Childish & & & & & & & nary & & & & \\
\hline $\begin{array}{c}3 \text { year } \\
\mathrm{s}\end{array}$ & $\begin{array}{c}4 \text { year } \\
\mathrm{s}\end{array}$ & $\begin{array}{c}5 \text { year } \\
\mathrm{s}\end{array}$ & 1st & 2nd & 3rd & & th & & & & 6th & \\
\hline 0 & 0 & 0 & 0 & 0 & 0 & & 5 & & & & 72 & \\
\hline & High & chool & & & & & Trainir & $\overline{\mathrm{Cycl}}$ & & $\begin{array}{r}\text { Unive } \\
\text { Sev }\end{array}$ & $\begin{array}{l}\text { ity of } \\
\text { (1) }\end{array}$ & $\begin{array}{l}\text { Other } \\
\text { (3) }\end{array}$ \\
\hline & & & & & & & $\begin{array}{l}\text { ade } \\
\text { dium }\end{array}$ & & $\begin{array}{l}\text { ade } \\
\text { her }\end{array}$ & $\begin{array}{l}\text { Grade } \\
\text { (two) }\end{array}$ & $\begin{array}{c}\text { Master } \\
\text { (one) }\end{array}$ & \\
\hline $1 \mathrm{st}$ & 2nd & $3 r d$ & 4th & $1 \mathrm{st}$ & 2nd & $1 \mathrm{st}$ & 2nd & $1 \mathrm{st}$ & 2nd & & & \\
\hline 116 & 36 & 39 & 40 & 95 & 30 & 53 & & 77 & 60 & 25 & 5 & 7 \\
\hline
\end{tabular}

Broadly speaking, the second sample doubled, in almost all aspects, the results of the first. The new incorporation of the University of Seville among the 22 participating organizations is very relevant. A total of 49 teachers accompanied the 705 students each day. This edition was also covered by the media ${ }^{2}$.

\subsection{MUAC 2018.}

The third experience took place on May 10, 2018. Of the 41 workshops, 10 were part of the Murillo Year project. This city project is a multidisciplinary event that involves various institutions to bring baroque painting to citizens through a program of cultural activities, restoration and research that aims to draw new routes for the study of the painter and his time. The chosen spaces were again: the Palace of the Marquises of the Algaba, the House of the Sirens, and the location of the Alameda de Hércules.

Table 3. Number of total participants, by courses and educational levels in III MuAC.

\begin{tabular}{|c|c|c|c|c|c|c|c|c|c|c|c|c|}
\hline \multicolumn{13}{|c|}{ MuAC 2018 (1010 Students) } \\
\hline \multicolumn{3}{|c|}{ Childish } & \multicolumn{10}{|c|}{ Primary } \\
\hline $\begin{array}{c}3 \\
\text { years }\end{array}$ & $\begin{array}{c}4 \\
\text { years }\end{array}$ & $\begin{array}{c}5 \\
\text { years }\end{array}$ & 1st & 2nd & 3rd & \multicolumn{2}{|c|}{ 4th } & \multicolumn{2}{|c|}{ 5th } & \multicolumn{3}{|c|}{ 6th } \\
\hline 0 & 50 & 25 & 50 & 0 & 25 & \multicolumn{2}{|c|}{25} & \multicolumn{2}{|c|}{179} & \multicolumn{3}{|c|}{117} \\
\hline \multirow{2}{*}{\multicolumn{4}{|c|}{ High school }} & \multirow{2}{*}{\multicolumn{2}{|c|}{ high school }} & \multicolumn{4}{|c|}{ Training Cycles } & \multicolumn{2}{|c|}{ University of Seville (1) } & $\begin{array}{l}\text { Other } \\
\text { (12) }\end{array}$ \\
\hline & & & & & & \multicolumn{2}{|c|}{$\begin{array}{c}\text { Grade } \\
\text { Medium }\end{array}$} & \multicolumn{2}{|c|}{$\begin{array}{l}\text { Grade } \\
\text { Higher }\end{array}$} & $\begin{array}{c}\text { Grade } \\
\text { (4) }\end{array}$ & $\begin{array}{c}\text { Master } \\
\text { (two) }\end{array}$ & \\
\hline $1 \mathrm{st}$ & 2nd & $3 r d$ & 4th & $1 \mathrm{st}$ & 2nd & $1 \mathrm{st}$ & 2nd & $1 \mathrm{st}$ & 2nd & & & \\
\hline 101 & 79 & 48 & 13 & 29 & 0 & 8 & & 88 & 80 & 40 & 6 & 47 \\
\hline
\end{tabular}

We can say that the third edition trebled data of the first edition, with more than a thousand students and 87 teachers involved.It should be noted that all educational stages are represented, and almost all courses or levels. In the line of previous editions, the press, radio and television echoed the event ${ }^{3}$.

After the analysis of the information collected in the three editions of the Annual Communication Sample, we can establish a comparison between them, which reflects the number of participants per each edition year, educational levels, and participating teaching centers.

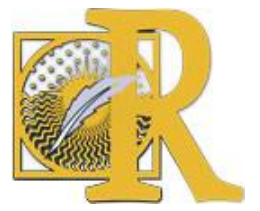


Table 4. Comparisons of MuAC editions (I, II and III MuAC).

\begin{tabular}{|c|c|c|c|c|c|c|c|c|c|c|c|c|}
\hline \multirow[t]{2}{*}{ Year } & \multirow[t]{2}{*}{$\begin{array}{c}\text { No. of } \\
\text { Schools that } \\
\text { participated }\end{array}$} & \multicolumn{2}{|c|}{$\begin{array}{l}\text { Number of students } \\
\text { who participated by } \\
\text { educational stage }\end{array}$} & \multirow[t]{2}{*}{$\begin{array}{c}\text { No. of } \\
\text { Institutes } \\
\text { that } \\
\text { participated }\end{array}$} & \multicolumn{3}{|c|}{$\begin{array}{c}\text { Number of students who } \\
\text { participated by educational } \\
\text { stage }\end{array}$} & \multirow[t]{2}{*}{$\begin{array}{c}\text { No. of } \\
\text { Universities } \\
\text { that } \\
\text { participated }\end{array}$} & \multicolumn{2}{|c|}{$\begin{array}{c}\text { Number of } \\
\text { students who } \\
\text { participated by } \\
\text { educational stage }\end{array}$} & \multirow[t]{2}{*}{$\begin{array}{l}\text { No. of Other } \\
\text { Organizations } \\
\text { who } \\
\text { participated }\end{array}$} & \multirow[t]{2}{*}{$\begin{array}{c}\text { No. of } \\
\text { students who } \\
\text { participated }\end{array}$} \\
\hline & & Childish & Primary & & $\begin{array}{c}\text { High } \\
\text { school }\end{array}$ & $\begin{array}{c}\text { high } \\
\text { school }\end{array}$ & $\begin{array}{l}\text { Training } \\
\text { Cycles }\end{array}$ & & Grade & Master & & \\
\hline 2016 & 4 & 2 & 83 & 4 & 126 & 4 & 62 & 0 & 0 & 0 & 2 & 1 \\
\hline 2017 & 5 & 0 & 122 & 13 & 231 & 125 & 190 & 1 & 25 & 5 & 3 & 7 \\
\hline 2018 & 12 & 75 & 396 & 9 & 241 & 29 & 176 & 1 & 40 & 6 & 12 & 47 \\
\hline
\end{tabular}

Figure 1. Diachronic analysis of the participation of students in the three editions of MuAC

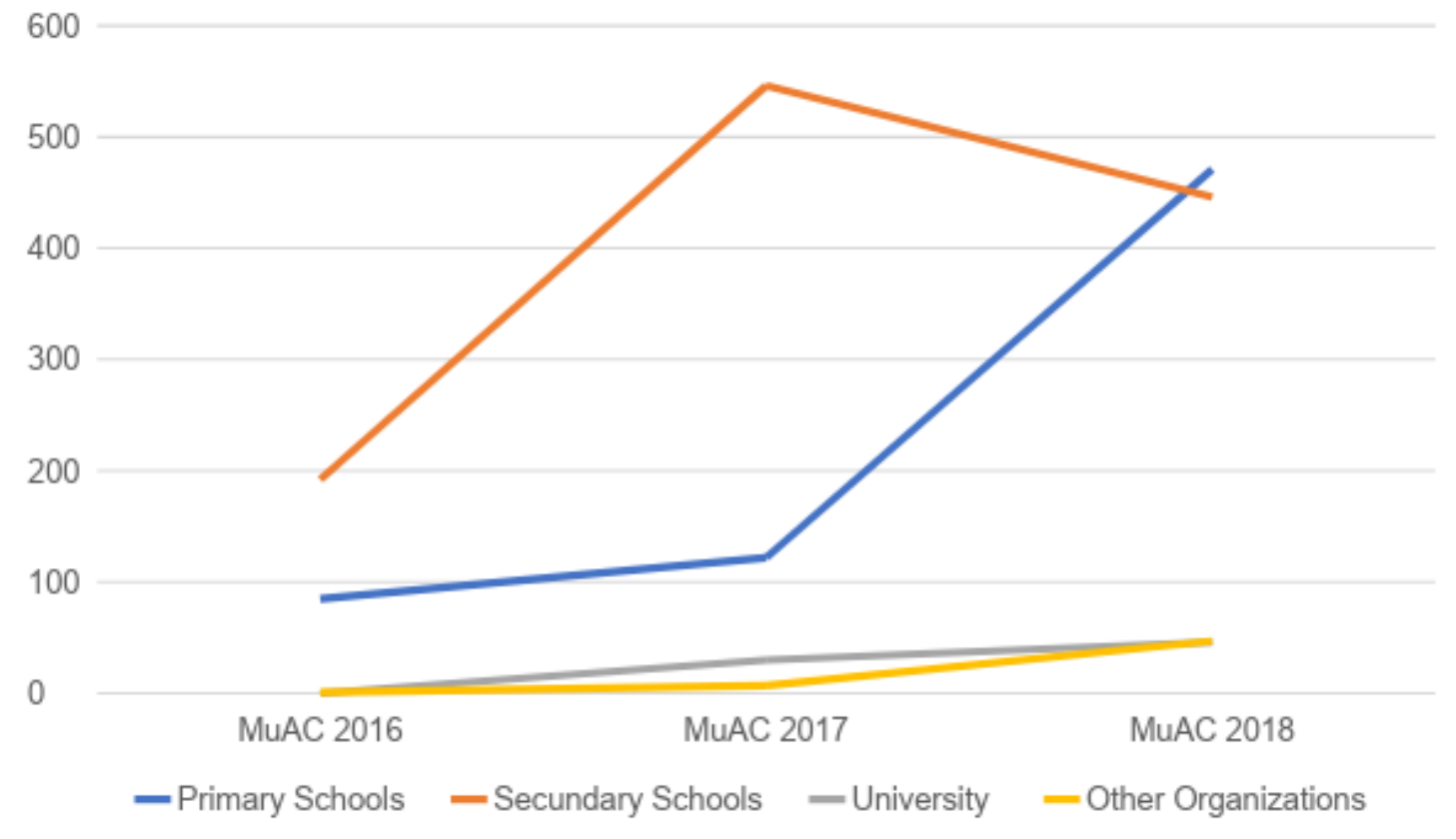

After observing the data, we can see a significant increase in the number of students who carried out the teaching-learning activities proposed by the MuAC initiative, except in the case of high school students who substantially decreased their participation.

\subsection{Questionnaire.}

One of the instruments used to assess the educational experience at each meeting edition, is a questionnaire Likert scale, with a gradient or valuation level 1 to 5 (where 1 indicates "not satisfied", 2 "bit satisfied", 3 "undecided", 4 "satisfied ", and 5 "very satisfied"). The instrument is composed of 8 items:

Item 1. Overall satisfaction after the event.

Item 2. Educational usefulness of the activities presented.

Item 3. Degree of pedagogical innovation of the activities.

Item 4. Protagonism of education in values.

Item 5. Intergenerational and intercultural approach to the event.

Item 6. Involvement and participation of students.

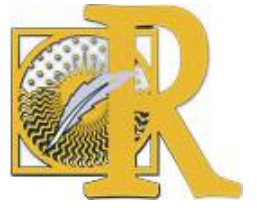

Fecha de recepción: 25-02-2019 Fecha de aceptación: 09-07-2020 
Item 7. Adaptation of the participatory methodology.

Item 8. Satisfaction about the exchange of teaching experiences.

Next, the descriptive analyzes of the data collected in the evaluation questionnaires for the three editions of MuAC made:

Table 5. Descriptive statistics MuAc 2016, 2017 and 2018.

\begin{tabular}{|c|c|c|c|c|c|c|c|c|c|}
\hline \multicolumn{10}{|c|}{ MuAc 2016} \\
\hline & & Item 1 & Item 2 & Item 3 & Item 4 & Item 5 & Item 6 & Item 7 & Item 8 \\
\hline \multirow[t]{2}{*}{$\mathrm{N}$} & Valid & 3.4 & 3.4 & 3.4 & 3.4 & 3.4 & 3.4 & 3.4 & 3.4 \\
\hline & Lost & 0 & 0 & 0 & 0 & 0 & 0 & 0 & 0 \\
\hline \multicolumn{2}{|c|}{ Half } & 4.03 & 4.26 & 3.85 & 4 & 4.21 & 4.09 & 4.38 & 4.32 \\
\hline \multicolumn{2}{|c|}{ Median } & 4 & 4 & 4 & 4 & 4 & 4 & 5 & 4.50 \\
\hline \multicolumn{2}{|c|}{ Fashion } & 4 & 4 & 4 & 4 & 4 & 4 & 5 & 5 \\
\hline \multicolumn{2}{|c|}{ Standard deviation } & .797 & .751 & .702 & .696 & .687 & .866 & .853 & .806 \\
\hline \multicolumn{2}{|c|}{ Variance } & .635 & .564 & .493 & .485 & .471 & .750 & .728 & .650 \\
\hline \multicolumn{10}{|c|}{ MuAc 2017} \\
\hline & & Item 1 & Item 2 & Item 3 & Item 4 & Item 5 & Item 6 & Item 7 & Item 8 \\
\hline \multirow[t]{2}{*}{$\mathrm{N}$} & Valid & 49 & 49 & 49 & 49 & 49 & 49 & 49 & 49 \\
\hline & Lost & 0 & 0 & 0 & 0 & 0 & 0 & 0 & 0 \\
\hline \multicolumn{2}{|c|}{ Half } & 4.20 & 4.37 & 3.92 & 4.10 & 4.35 & 4.16 & 4.43 & 4.35 \\
\hline \multicolumn{2}{|c|}{ Median } & 4 & 4 & 4 & 4 & 4 & 4 & 5 & 5 \\
\hline \multicolumn{2}{|c|}{ Fashion } & 4 & 4 & 4 & 4 & 4 & 4 & 5 & 5 \\
\hline \multicolumn{2}{|c|}{ Standard deviation } & .790 & .698 & .759 & .684 & .663 & .773 & .764 & .779 \\
\hline \multicolumn{2}{|c|}{ Variance } & .624 & .487 & .577 & .469 & .440 & .598 & .583 & .606 \\
\hline \multicolumn{10}{|c|}{ MuAc 2018} \\
\hline & & Item 1 & Item 2 & Item 3 & Item 4 & Item 5 & Item 6 & Item 7 & Item 8 \\
\hline \multirow[t]{2}{*}{$\mathrm{N}$} & Valid & 87 & 87 & 87 & 87 & 87 & 87 & 87 & 87 \\
\hline & Lost & 0 & 0 & 0 & 0 & 0 & 0 & 0 & 0 \\
\hline \multicolumn{2}{|c|}{ Half } & 4.34 & 4.49 & 4.16 & 4.36 & 4.38 & 4.32 & 4.51 & 4.43 \\
\hline \multicolumn{2}{|c|}{ Median } & 4 & 5 & 4 & 4 & 4 & 4 & 5 & 5 \\
\hline \multicolumn{2}{|c|}{ Fashion } & 4 & 5 & 4 & 4 & 4 & 4 & 5 & 5 \\
\hline \multicolumn{2}{|c|}{ Standard deviation } & .697 & .626 & .761 & .664 & .651 & .739 & .663 & .772 \\
\hline \multicolumn{2}{|c|}{ Variance } & .461 & .392 & .578 & .441 & .424 & .546 & .439 & .596 \\
\hline
\end{tabular}

In the 2016 edition, $23.5 \%$ of respondents indicated that they felt very satisfied after the event, $38.2 \%$ found the activities carried out with great educational value, $58.8 \%$ were satisfied with the degree of pedagogical innovation, and $70.6 \%$ say they are satisfied with the stressed presence of education in values. On the intergenerational and intercultural approach, $50 \%$ indicate to be satisfied, and $35.3 \%$ very satisfied. On the other hand, $52.9 \%$ admit being satisfied with the involvement and participation of students, and $55.9 \%$ is very satisfied with the exchange of teaching experiences. Finally, on the adequacy of the participatory methodology used in the experience, $35.3 \%$ indicate to be satisfied, and $50 \%$ very satisfied. In the 2017 edition, $30.6 \%$ of respondents indicated that they felt very satisfied after the event and $59.2 \%$ satisfied. $44.9 \%$ found the activities carried out with great educational value, $49 \%$ were satisfied with the degree of pedagogical innovation and $65.3 \%$ said they were satisfied with the presence of education in values. Regarding the intergenerational intercultural approach, $44.9 \%$ indicate that they are very satisfied. On the other hand, $57.1 \%$ admit being satisfied with the involvement and participation of students and $55.1 \%$ is very satisfied with the exchange of teaching experiences. Finally, on the adequacy of the participative

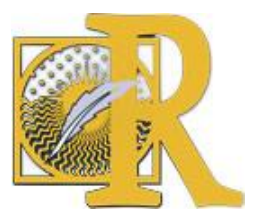


methodology that has been implemented in the experience, $34.7 \%$ indicate to be satisfied and $51 \%$ very satisfied.

In the 2018 edition, $42,5 \%$ of the respondents indicated that they were very satisfied after the event, $54 \%$ found the activities carried out with great educational value, $36,8 \%$ were very satisfied with the degree of pedagogical innovation and $43.7 \%$ satisfied. In addition, $50.6 \%$ say they are satisfied with the presence of education in values, and $43.7 \%$ very satisfied. On the intergenerational and intercultural approach, $47.1 \%$ said they were satisfied and $46 \%$ very satisfied. Finally, 49.4\% acknowledge being satisfied with the involvement and participation of students and $57.5 \%$ are very satisfied with the exchange of teaching experiences. Finally, on the adequacy of the participative methodology that has been implemented in the experience, $29.9 \%$ indicate to be satisfied, and $57.5 \%$ very satisfied.

\section{Discussion.}

In order to enrich the relationships established by people of different ages and to create common spaces of mutual learning, the possibility of intergenerational education is raised. We start from the idea of a heterogeneous society and we try to eliminate any conception of a homogeneous reality, since educating from common bonds facilitates the interaction and the exchange of values, and learning in favor of the construction of a diverse society where all people have equal respect, rights, and recognition.

This didactic proposal underlines the process of learning in a novel, fun, and meaningful way, as well as improving the interpersonal relationships of students of different ages and academic disciplines.

According to Martínez and Bedmar (2018), a contact established between students from two different age groups promotes mutual knowledge, in addition to contributing to inclusive education, without stereotypes between generations, since everyone can contribute something valuable to others by promoting values of respect, tolerance, and solidarity. In this sense, authentic learning is achieved by creating spaces for dialogue and exchange of different perspectives, dealing with topics of common interest from a complementary double vision.

According to the ideas of Pérez (1997), we can say that social pedagogy studies the potential of learning from coexistence. In this order of ideas, one must learn to live together in society, and this "Requires cultivating respect for diversity to the extent that it is taught to discover and eliminate injustices, and to solve differences in a constructive way" (Cabrera, Moreno and Fajardo, 2017, p.2).Therefore, in this type of experience the most important thing is to understand others from the individual differences that characterize them, since the real value of positive interactions is in group growth and learning, but always respecting one's own particularities, and the uniqueness of each individual (Díez, 2003).

According to Bedmar (2003), among the benefits of intergenerational education we can emphasize that it is an education throughout life that teaches how to live in society, develops interest in individual knowledge, promotes learning through reflection, interaction and action, but also allows you to be yourself, both individually and collectively.

The intergenerational experience can suppose a process of participation and social coexistence, that enriches the social relations as a base of development, and allows for the

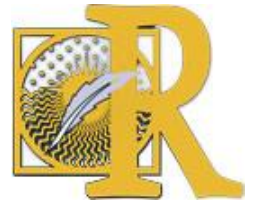

Fecha de recepción: 25-02-2019 Fecha de aceptación: 09-07-2020

Gallardo-López, J. A. \& Muñoz-Villaraviz, D. (2021). Metodologías participativas con un enfoque intercultural e intergeneracional. Una experiencia educativa en la ciudad 
possibility of changing the individual and collective circumstances (Muñoz, 2017). These intergenerational educational activities, where there is an approximation between different ages, are a fundamental tool to work on transversality in the development of democratic, civic, and ethical values. In addition, these experiences, properly oriented, encourage the treatment of diversity and respect for human rights, and the basic freedoms of all people (Montero and Baena, 2013).

Normally, we are accustomed to using social spaces for leisure and free time and to develop educational processes that are very determined by age. In this sense, experiences which break with the established view, creating common spaces of generational exchange for learning, suppose civic exercises with a highly positive impact for all involved. In fact, we can say that a society cannot develop or evolve if its population groups do not establish continuous interrelations (Montero and Bedmar, 2009, Montero, García and Bedmar, 2011).

The involvement of the educational community in this type of pedagogical experiences is fundamental, forming part of the activities that are posed with the students in a direct manner. Studies like those of Jensen, Joseng and Lera (2007) or Montesinos, Martínez, Pomares and Serrano (2013), confirm that establishing a greater commitment and cohesion between family and school, the educational quality increases. These types of activities involve the implementation of teaching and learning strategies, necessary and innovative, to enhance integration among students of different ages, their teachers, their families, and staff- from different organizations and institutions linked to the school. In addition, they are carried out in key points of the city, in spaces shared by citizens, leaving the classrooms and opening the school to its closest social context with the aim of facilitating the integral development of the students, promoting and stimulating different forms of relations in terms of plurality, recognizing differences and multiplicity.

The participating students discover different areas of the city through the people who inhabit these spaces, breaking prejudices and labels pervasive in certain neighborhoods, or districts of the city. The individual's concept of the city, which is sometimes limited to his or her neighborhood, is enriched.

On the other hand, the activities planned from an intergenerational perspective occupying common spaces in the city also promote unexpected encounters and intercultural relationships. In this way, students, teachers, and faculty from different neighborhoods, share common spaces and interrelate with the objective of sharing experiences and cooperative and collaborative learning.

The relationships between people of different ages and different social, cultural, and economic characteristics, establish an unbeatable opportunity to build links among different groups. In addition to sharing spaces for leisure and free time, relational synergies are created for the exchange of interests, ideas, feelings, values and learning, thus enabling a critical and reflective perspective.

According to Iglesias and Espona (2017), "it is assumed that it is a condition for inter-culturality to generate spaces of relationship between young people of different cultural origins and social conditions" (p.148).

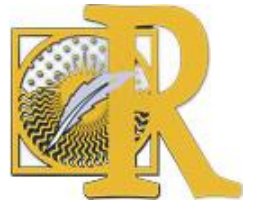

Fecha de recepción: 25-02-2019 Fecha de aceptación: 09-07-2020 Gallardo-López, J. A. \& Muñoz-Villaraviz, D. (2021). Metodologías participativas con un enfoque intercultural e intergeneracional. Una experiencia educativa en la ciudad 
From the educational point of view, the social approach to pedagogy is essential. We must educate in social and cultural spaces where contact and the relationship among citizens promote coexistence, miscegenation and diversity (Figueredo and Ortiz, 2018). These intercommunity processes are a great tool for mediation since they establish scenarios of dialogue, relationship, and democratic participation (Márquez, Prados and Padua, 2018).

Following Escarbajal and Leiva (2017), we can say that the success or failure of the inclusion of immigrants in the educational centers of our country, "depends to a large extent on the attitudes and behaviors that are developed in the classroom and in the school as a whole on the part of the students, also of the families, but above all of the teaching staff " (p.282). For this reason, the training and attitude of teachers in the face of interculturality is a key to the proper functioning of socio-educational practices.

This concern for the multicultural from the educational field has led to various authors such as Banks (2014), Olmos (2016), Martínez, Lloret and Céspedes (2017) or Verdeja (2018) approaching, with their research, to the challenges that this problem generates. In this sense, the attention given to cultural diversity is a teaching challenge of our time, and we must approach it proposing new methodological ways that allow us to fulfill in practice the objectives that we propose. Since, at present, the approach of traditional pedagogies is not very adequate to address the multiple processes by which students acquire their skills, "understood as the ability to respond to complex demands through the internalization of knowledge, skills, emotions, values and attitudes" (Fernández, Fernández and Rodorigo, 2017, p. 484).

We agree with Rodríguez (2018) that interculturality must be worked on from the schools, but "opening up to the participation of the whole educational community ... and, above all, educating for personal, social, community values, development towards the educational transformation at all levels " (p.53). Therefore, an authentic intercultural education must configure the school as a meeting place among cultures, open to the community, where education favors democracy and coexistence; and not only as hermetic spaces for the transmission of educational content.

Therefore, we can deduce that building the conditions for a positive social coexistence is, above all, an educational issue. This implies addressing this great challenge from the exchange of learning experiences with heterogeneous groups, taking into account cultural, generational, and diverse socio-educational characteristics (Fiorucci, 2017).

In short, intergenerational and intercultural educational projects carried out in common spaces, such as MuAC (Annual Exhibition of Communication) are becoming increasingly necessary. This need is manifested in the progressive increase in demand by teachers to participate in MuAC, edition after edition.

In addition, the flexible and efficient format of the educational event of the MuAC project guarantees the success of the activity, and its possible exportation to other territorial contexts. Likewise, the active role of all the students and teaching staff, encourages the establishment of constructive and balanced relationships, in a relaxed atmosphere and cordiality that continues with the broad cultural, social, and generational diversity, is presented as an additional attraction in that space of confluences, eliminating prejudices and improving coexistence, harmonizing knowledge and entertainment.

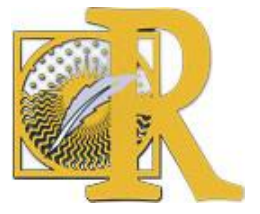

Fecha de recepción: 25-02-2019 Fecha de aceptación: 09-07-2020 Gallardo-López, J. A. \& Muñoz-Villaraviz, D. (2021). Metodologías participativas con un enfoque intercultural e intergeneracional. Una experiencia educativa en la ciudad International Journal of Educational Research and Innovation (IJERI), 16, 74-87 ISSN: 2386-4303 DOI https://doi.org/10.46661/ijeri.3792 


\section{References.}

- Abarrategui, L. (2018). Radio intergeneracional en la escuela: una propuesta para el envejecimiento activo. index.comunicación, 8 (2), 211-228.

- Ainscow, M; \& Booth, T. (2002). Guía para la evaluación y mejora de la educación inclusiva. Index for inclusion. Madrid: Consorcio Universitario para la Inclusión Educativa.

- Banks, J.A. (2014). Emigración global, diversidad y educación para la ciudadanía. Revista Electrónica Interuniversitaria de Formación del Profesorado, 17 (2), 1-11.

- Bedmar, M. (2003). La Educación Intergeneracional encierra un tesoro. En M.Cabrera, F; Moreno, D; \& Fajardo, D. (2017). Treatment to intergenerational coexistence in primary school. EduSol, $17(59), 1-9$.

- Chamseddine, M. (2018). Polarización escolar en España. Retos e implicaciones International Journal of Educational Research and Innovation (IJERI), 9, 189-205.

- Cotán Fernández, A; García-Lázaro, I; \& Gallardo-López, J. A. (2021). Trabajo colaborativo en línea como estrategia de aprendizaje en entornos virtuales: una investigación con estudiantes universitarios de Educación Infantil y Educación Primaria. Educación, 30 (58), 147-168. https://doi.org/10.18800/educacion.202101.007.

- Díez, R. (2003). Documento básico de trabajo. En Aprender para el futuro. Educación para la convivencia democrática (pp. 37-40). Madrid: Fundación Santillana.

- Echeita, G; Simón, C; Sandoval, M; \& Monarca, H. (2013). Cómo fomentar las redes naturales de apoyo en el marco de una escuela inclusiva: propuestas prácticas. Sevilla: Editorial MAD.

- Escarbajal, A; \& Leiva, J.J. (2017). La necesidad de formar en competencias interculturales como fundamento pedagógico: Un estudio en la región de Murcia (España). Profesorado. Revista de currículum y formación del profesorado, 21 (1), 281-293.

- Fernández, S; Fernández, J; \& Rodorigo, M. (2017). Expectativas socioeducativas de alumnas inmigrantes: escuchando sus voces. Revista de Investigación Educativa, 35 (2), 483-498.

- Figueredo, V; \& Ortiz, L. (2018). Profesorado y Diversidad Cultural: Análisis de la formación inicial del profesorado en interculturalidad. International Journal of Educational Research and Innovation (IJERI), 9, 46-71.

- Fiorucci, M. (2017). Educar a la ciudadanía global en una perspectiva intercultural. Revista Española de Educación Comparada, 30, 44-60.

- Formiya, M; \& Rodríguez, C. (2017). Propuesta para la mejora del aprendizaje y la convivencia en un instituto bilingüe y multicultural de Madrid. Debates \& Prácticas en Educación, 2, 49-68.

- García, J. (2012). Transformación del entorno. Comunidades de Aprendizaje. Escuela, 8, 1-8.

- García, J; \& Villar, C. (2011). La aportación del proyecto de comunidades de aprendizaje a la transformación social y educativa de un barrio. La experiencia de La Estrella y La Milagrosa en Albacete. Tendencias Pedagógicas, 18, 207-232.

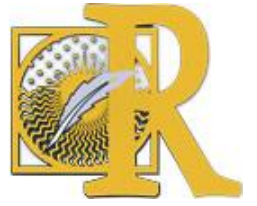

Fecha de recepción: 25-02-2019 Fecha de aceptación: 09-07-2020 
- Gallardo-López, J. A; \& Gallardo Vázquez, P. (2018). Teorías del juego como recurso educativo. En E. López-Meneses, D. Cobos-Sanchiz, A.H. Martín-Padilla, L. Molina-García y A. Jaén-Martínez (Eds.). INNOVAGOGÍA 2018. IV Congreso Virtual Internacional sobre Innovación Pedagógica y Praxis Educativa (p. 356). Sevilla, España: AFOE.

- Gallardo Vázquez, P; \& Gallardo-López, J. A. (2011a). La Educación Social como objeto de estudio de la Pedagogía Social. Actas de la II Jornada Monográfica de la Sociedad Iberoamericana de Pedagogía Social. Pedagogía Social y Educación Social. una Mirada al Futuro (pp. 288-301). Madrid, España.

- Gallardo Vázquez, P; \& Gallardo-López, J. A. (2011b). Pedagogía Social. Sevilla: Editorial Wanceulen.

- George, D. \& Mallery, P. (2003). SPSS for Windows step by step: A simple guide and reference. 11.0 update. Boston: Allyn \& Bacon.

- González-Cutre, D., Sicilia, A., Sierra, A. C., Ferriz, R., y Hagger, M. S. (2016). Understanding the need for novelty from the perspective of self-determination theory. Personality and Individual Differences, 102, 159-169.

- Iglesias, E; \& Espona, E. (2017). Propuestas para el desarrollo de la interculturalidad en la educación en el tiempo libe de base comunitaria en Cataluña. Pedagogía social. Revista interuniversitaria, 30, 145-157.

- Jensen, K.; Joseng, F. \& Lera, M. J. (2007). Familia y escuela. Programa Golden 5, 1-11.

- Johnson, D.W; \& Johnson, R.T. (2009). An educational psychology success story: social interdependence theory and cooperative learning. Educational Researcher, 38 (5), 365379.

- Leiva, J.J. (2017). Luces y sombras en la construcción de una educación intercultural en tiempo de incertidumbre. Modulema. Revista Científica sobre Diversidad Cultural, 1, 2139.

- Lozano, J; Cerezo, M.C; \& Alcaraz, S. (2015). Plan de atención a la diversidad. Madrid: Alianza Editorial.

- Olmos-Alcaraz, A. (2016). Diversidad lingüístico-cultural e interculturalismo en la escuela andaluza: Un análisis de políticas educativas. Relieve, 22 (2),1-20.

- Pérez, G. (1997). Cómo educar para la democracia. Estrategias educativas. Madrid: Editorial Popular.

- Márquez, Ma . J; Prados, Mạ. E; \& Padua, D. (2018). La voz de Tsura. Un relato biográficonarrativo sobre mediación intercultural y su sentido resiliente en el ámbito educativo. Educar, 54 (1) 49-66.

- Martínez, N; \& Bedmar, M. (2018). Aprendizaje basado en la experiencia. Programa de educación intergeneracional. En-clave pedagógica, 14, 8-14.

- Martínez, M.J; Lloret, C; \& Céspedes, M. (2017). Lo que hacen las mejores escuelas integradoras de alumnado inmigrante: indicadores de buenas prácticas Pedagogía Social. Revista Interuniversitaria, 29, 41-54.

- MECD, (2017). Datos y Cifras. Curso escolar 2017/2018. Servicio de Publicaciones del Ministerio de Educación, Cultura y Deportes.

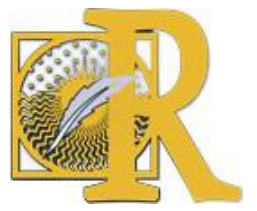

Fecha de recepción: 25-02-2019 Fecha de aceptación: 09-07-2020 Gallardo-López, J. A. \& Muñoz-Villaraviz, D. (2021). Metodologías participativas con un enfoque intercultural e intergeneracional. Una experiencia educativa en la ciudad International Journal of Educational Research and Innovation (IJERI), 16, 74-87 ISSN: 2386-4303 DOI https://doi.org/10.46661/ijeri.3792 
- Moliner, O; Moliner, L; Sanahuja, A; \& Sanmateo, V. (2015). Análisis de los elementos de la tutoría entre iguales que posibilitan avanzar hacia la construcción de una escuela intercultural inclusiva y democrática. Revista latinoamericana de educación inclusiva, 9 (2), 41-58.

- Montero, I; \& Baena, T. (2013). Experiencias innovadoras en el ámbito de la educación infantil en España. El valor de las relaciones intergeneracionales. Educación y ciudad, 24, 93-105.

- Montero, I; \& Bedmar, M. (2009). Reconstrucción de vivencias desde la educación intergeneracional: experiencia docente e innovación a través de la historia oral. En VII Congreso Internacional de Historia Oral. México: Universidad de Colima.

- Montero, I; García, J; \& Bedmar, M. (2011). Ciudadanía activa y personas mayores. Contribuciones desde un modelo de educación expresiva. Revista Iberoamericana de Educación. RIE, 55 (5), 1-13.

- Montesinos, A. M.; Martínez, A.; Pomares, C. \& Serrano, F. J. (2013). El papel de los abuelos en la educación de sus nietos. La percepción de los padres y madres del alumnado de educación infantil. En I Congreso Internacional y II Congreso Nacional de Investigación e Innovación en Educación Infantil y Educación Primaria. España: Universidad de Murcia.

- Muñoz, Má. R. (2017). El enfoque intergeneracional: del contexto global al contexto local de Alcobendas. RES Revista de Educación Social, 25, 1-29.

- Quaresma, M.L; \& Zamorano, L. (2016). El sentido de pertenencia en escuelas públicas de excelencia. Revista Mexicana de investigación educativa, 11 (68), 275-298.

- Rodríguez, Ma . R. (2018). Aportes para el desarrollo de prácticas interculturales con perspectiva coeducativa en centros escolares: La educación social como herramienta de cambio en el ámbito reglado. En-clave pedagógica, 14, 52-59.

- Santos, M.A. (2017). La educación intercultural y el pluralismo religioso: Propuestas pedagógicas para el diálogo. Educación XXI, 20 (1), 17-35.

- Traver, J; Sales, A; \& Moliner, O. (2010) Ampliando el territorio: algunas claves sobre la participación de la comunidad educativa. Revista Iberoamericana sobre Calidad, Eficacia y Cambio en Educación, 8 (3), 97-119.

- UNESCO. (2006). Directrices de la UNESCO sobre la educación intercultural. Paris: Ediciones UNESCO.

- Verdeja, M. (2018). Percepciones del profesorado, alumnado y familias ante la diversidad cultural: el caso de un IES asturiano. Tendencias pedagógicas, 31, 227-252.

\footnotetext{
${ }^{1}$ Article published in the newspaper El Correo de Andalucía: http://ow.ly/kl6B30mT5Jr

Report made in "In first person" program of Radio Nacional de España: http://ow.Iy/JgmL30mT5Ps

${ }^{2}$ Article published in Diario de Sevilla: http://ow.ly/dXi330mT6rW

${ }^{3}$ Article published in Diario de Sevilla: http://ow.ly/1v1a30mT6wE

Report made in "Artesfera en Radio 5" program of Radio Nacional de España: http://ow.ly/alZQ30mT6EU

Report made in "In first person" program of Radio Nacional de España: http://ow.ly/aL9730mT6KP

Report made on Canal Sur Televisión: http://ow.ly/S6dG30mT608
}

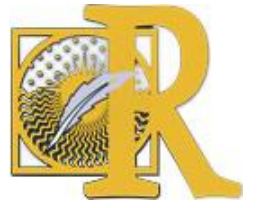

Fecha de recepción: 25-02-2019 Fecha de aceptación: 09-07-2020

Gallardo-López, J. A. \& Muñoz-Villaraviz, D. (2021). Metodologías participativas con un enfoque intercultural e intergeneracional. Una experiencia educativa en la ciudad

International Journal of Educational Research and Innovation (IJERI), 16, 74-87 ISSN: 2386-4303 DOI https://doi.org/10.46661/ijeri.3792 